\title{
Process Concept for the Dry Recovery of Thermal Energy of Liquid Ferrous Slags
}

\author{
Felix Firsbach $^{1,2}\left[\right.$ Dieter Senk $^{1} \cdot$ Alexander Babich $^{1}$
}

Received: 16 April 2021 / Accepted: 9 June 2021 / Published online: 24 June 2021

(c) The Author(s) 2021

\section{Abstract}

Slags are valuable by-products of iron- and steelmaking processes. Their efficient reutilization and the recuperation of their thermal energy are key for improving the overall efficiency of these processes. With the innovative approach presented in this work, it is possible to recover thermal heat from liquid slags. The process concept consists of a slag tundish and four subsequent heat exchangers. The liquid slag is poured into the slag tundish which homogenizes the slag and guarantees a constant mass flow. The heat exchangers extract thermal energy from the slag and transfer it to water or oil. The first module cools the slag from the tapping temperature of about $1500{ }^{\circ} \mathrm{C}$ down to $850{ }^{\circ} \mathrm{C}$. Inside the second module, more thermal energy is gathered from the already solidified slag cooling the slag down to ambient temperature. The captured energy can be used for various processes, such as gas preheating or generation of steam. The solidified slag is volume stable and forms amorphous phases, depending on its basicity. The process was designed, and the concept was tested on lab-scale demonstrators with an overall heat recovery rate of $42 \%$. Some applications of the recovered slag heat are also presented in this work.

\section{Graphical Abstract}

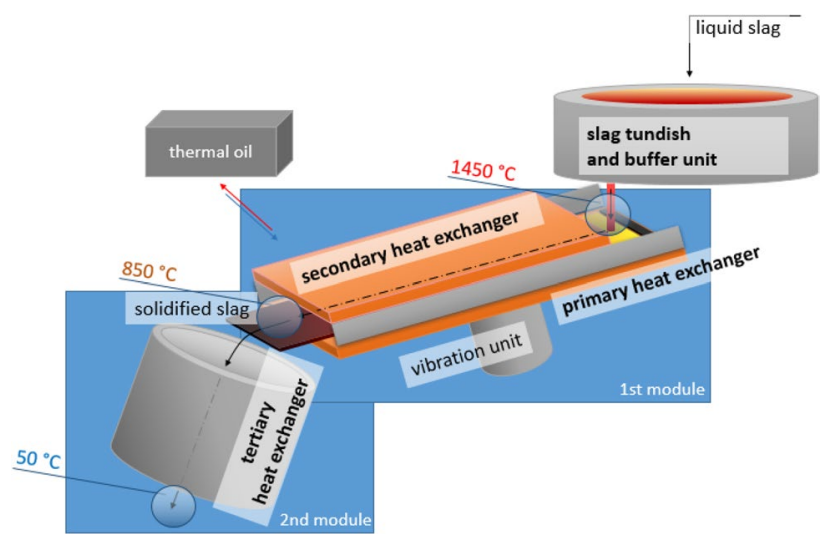

Scheme of the process concept with the three heat exchangers and buffer unit.

Keywords Iron and steelmaking $\cdot$ Slag $\cdot$ Heat recovery $\cdot$ Process concept

The contributing editor for this article was Joo Hyun Park.

Felix Firsbach

felix.firsbach@1hoist.com

1 Steel Institute (IEHK), RWTH Aachen University, Intzestraße 1, 52072 Aachen, Germany

2 Lhoist, Business Innovation Center (BIC), Rue de l'Industrie 31, 1400 Nivelles, Belgium

\section{Introduction}

Slags are valuable by-products from iron- and steelmaking processes performed worldwide [1]. Important factors for successful applications of slags are the chemical and mineralogical composition on the one hand and the recuperation of their thermal energy on the other hand. Industrial-scale 
applications incorporating the recycling of those by-products are common since many decades and include examples like (1) the grinding of water-quenched blast furnace slag (GGBFS) to receive hydraulic properties for their use in cement, (2) using stabilized slags as aggregates in roads and civil installations, (3) using free-lime and phosphorous containing converter slag as fertilizer (e.g., so-called "Konverterkalk" [2]) or (4) recycling of secondary metallurgical slags for re-introduction into the steel desulfurization process like Calexor ${ }^{\circledR}$ Aluminate. Current research is focusing on other topics like the recovery of precious metals such as chromium from slags via leaching [3] or the carbonization of slags for carbon capture and storage (CCS) [4] aiming to reach higher value creation of the slags than via the currently established methods described above. Thermal energy recovery of molten slags is left as one of the last resorts for optimizing the iron- and steelmaking processes regarding higher energy efficiency. In the processes of iron and steelmaking, industrial waste heat is recovered and re-used at most of the vessels. Examples of such a heat re-usage are, e.g., combustion of blast furnace top gas and coke oven gas (COG) for heating of hot stoves and electricity generation in steam boilers. The produced electricity makes the integrated steel plant independent of external supply and the oversupply is sold to the grid. The released energy of any molten slag during solidification on the other hand stays unused. Compared to other industries (Fig. 1), the iron and steel industry has the highest waste heat potential even in high value temperature ranges of $500{ }^{\circ} \mathrm{C}$ to more than $1000{ }^{\circ} \mathrm{C}$.

For this study, an exemplary blast furnace was selected with a slag production of $1770 \mathrm{t} / \mathrm{d}$ slag and respective specific annual heat loss of 1098 TJ/a. Depending on the yield of the heat recovery process, this heat potential could be interesting for internal energy recycling. Three possibilities are discussed later in this work. If a process for slag heat recovery is implemented with sufficient energy yields, the financial benefit is quantifiable depending on the energy's utilization. Assuming that the thermal energy is of sufficient temperature, it can be compared with natural gas heating.
Based on this assumption, calculated energy can be quantified as 5.10 EUR per ton hot metal produced, as shown in Table 1.

\section{Prior-Art}

Heat recovery from slag is a topic of research interest since at least the 1980s [5]. Different concepts have been tested and developed since then, but none has reached industrialization yet. Some of the more widely known concepts are described below to give an overview of the research landscape of the current subject.

As part of the Japanese project COURSE50 $\left(\mathrm{CO}_{2}\right.$ Ultimate Reduction in Steelmaking Process by Innovative Technology for Cool Earth 50) for the national reduction of $\mathrm{CO}_{2}$ emissions by $30 \%$ in Japan, the JFE Steel Corporation, the School of Engineering Osaka University, and the University of Tokyo investigated the Twin Roll Apparatus (TRA) for the rapid cooling of steel mill slag on cooling

Table 1 Slag's thermal energy potential based on exemplary Blast Furnace case with economic implications, excluding energy for drying slag

\begin{tabular}{ll}
\hline Parameter & Value \\
\hline Blast furnace working volume & $2400 \mathrm{~m}^{3}$ \\
Blast furnace hearth diameter & $10 \mathrm{~m}$ \\
Hot metal (HM) production & $5900 \mathrm{t} / \mathrm{d}$ \\
Productivity & $2.46 \mathrm{t} / \mathrm{d} \mathrm{m}^{3}$ \\
Specific slag rate & $300 \mathrm{~kg} / \mathrm{t}_{\mathrm{HM}}$ \\
Tapping temperature & $1,450^{\circ} \mathrm{C}$ \\
Specific heat capacity & $1.7 \mathrm{GJ} / \mathrm{t} \mathrm{slag}$ \\
Annual heat loss & $1098 \mathrm{TJ} / \mathrm{a}$ \\
Spec. heat loss & $0.51 \mathrm{GJ} / \mathrm{t}_{\mathrm{HM}}$ \\
Cost of natural gas (NG) & $10 € / \mathrm{GJ} \mathrm{NG}$ \\
Equivalent financial value & $10.98 \mathrm{Mio} € / \mathrm{a}$ \\
Specific financial value & $5.10 € / \mathrm{t}_{\mathrm{HM}}$ \\
\hline
\end{tabular}

Fig. 1 Waste heat per industrial sector and temperature level for EU in 2015 [20]

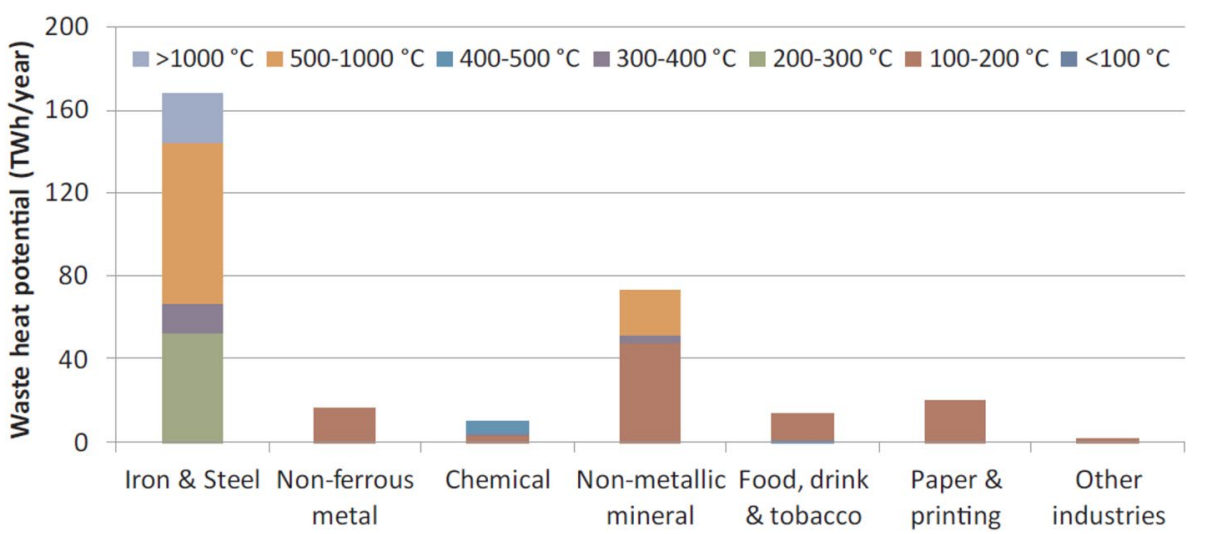


rollers, which are extended by downstream heat recovery. In order to increase the contact time between slag and copper cooling rollers, the direction of rotation was chosen to turn outwards, so that not one but two strands of slag plates are created, one on each roller. The roller dimensions are $1600 \mathrm{~mm}$ diameter and $1500 \mathrm{~mm}$ width. They rotate with $20 \mathrm{rpm}$ and are water cooled with a flow rate of $125-130 \mathrm{Nm}^{3} / \mathrm{h}$. The slag is poured with $1 \mathrm{t} / \mathrm{min}$ into the gap between the rollers, where it cools down to a temperature of approx. $1100{ }^{\circ} \mathrm{C}$ and solidifies with a height of $5 \mathrm{~mm}$. In this process step, the slag heat is not recovered. In a consecutive second step, the slag is conveyed into a cooling box, where the slag heat can be recovered batchwise in hot air of up to $450{ }^{\circ} \mathrm{C}$, which corresponds to a theoretical maximal heat recovery of $48 \%$ [6].

Mitsubishi Heavy Industries and JFE Steel Corporation developed the air blast granulation, which pours a thin film of molten slag. The slag is atomized with compressed air blown through nozzles from underneath the slag. The slag breaks into small droplets which are collected in a chamber for further heat recovery [7]. The process was successfully commercialized, also for non-ferrous slags, by Ecomaister and Hatch [8] with a $0-40 \%$ in hot air of up to $600{ }^{\circ} \mathrm{C}$ [9].

The spinning disk or spinning cup concept is the most developed of the chosen examples and seems close to industrialization. The molten slag is poured onto a spinning, water-cooled copper disk or cup and dispersed to small particles of approx. $900{ }^{\circ} \mathrm{C}$ via centrifugal force. The heat is recovered in a consecutive step via hot air up to $600{ }^{\circ} \mathrm{C}$. The concept is in development by the Commonwealth Scientific and Industrial Research Organisation (CSIRO) [10] and Primetals [11]. While this technology approach is the most mature, the remaining challenge is the limited slag capacity of $2 \mathrm{t} / \mathrm{min}$, which needs buffering in the case of blast furnace slag, as the mass flow can peak at $7 \mathrm{t} / \mathrm{min}$.

The vibrating copper chute concept that was investigated in parallel to the present studies initial research by the copper producer KME, FEhS, and Georgsmarinenhütte in lab and pilot scale in the frame of the DEWEOS project [12]. The vibrating chute concept of this consortium includes a copper plate with $1.5 \times 2.0 \mathrm{~m}$ contact area, which is water cooled via channels inside the copper plate. The vibration is performed at $10-20 \mathrm{~Hz}$ and an inclination angle of $3^{\circ}$. Molten slag is poured onto the device and cooled down to approx. $1000{ }^{\circ} \mathrm{C}$ with a plate height of $10-15 \mathrm{~mm}$. Slag heat recovery is not implemented in pilot scale but foreseen as a consecutive step after solidification.

\section{Process Concept}

A new approach for dry heat recovery $[13,14]$ has been investigated to address the challenge of separating amorphous solidification of blast furnace slag from heat recovery. The chosen approach is designed to recover heat from slags during its solidification. The general concept behind the process is the dry recovery of thermal energy of metallurgical slags via indirect cooling and energy capture with water or thermal oil. The application of the concept is further shown in the example of blast furnace slag (BFS). The concept (Fig. 2) comprises 5 parts: (1) slag tundish, (2) primary heat exchanger (PHE), (3) secondary heat exchanger (SHE), (4) tertiary heat exchanger (THE), and (5) quaternary heat exchanger (QHE). The tapped liquid slag
Fig. 2 Scheme of the process concept

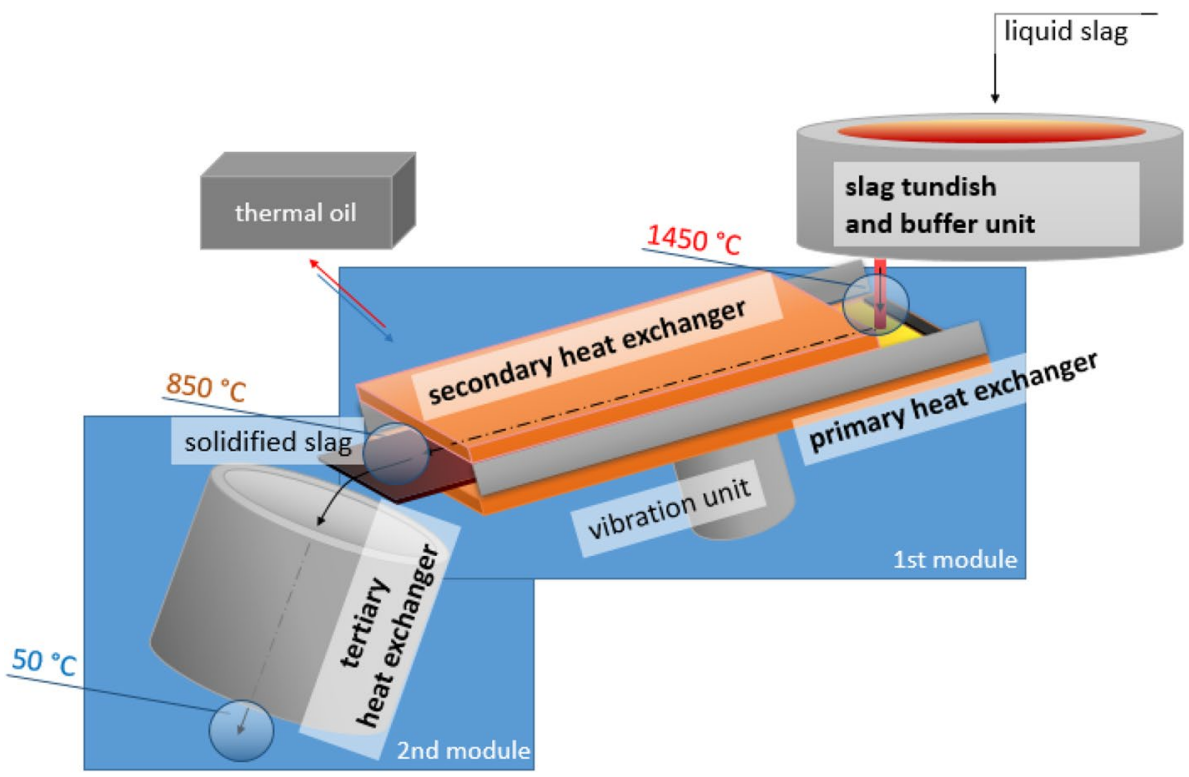


is poured into the slag tundish which homogenizes the slag mass flow while reducing the heat sink in this buffer unit. The primary, secondary, and tertiary heat exchangers extract thermal energy from the slag and transfer it to water or thermal oil. While the primary and secondary heat exchanger are part of the first module directly after the slag tundish, the tertiary heat exchanger is part of the second module. The first module cools the slag from the respective tapping temperature of about $1450{ }^{\circ} \mathrm{C}$ down to around $850{ }^{\circ} \mathrm{C}$ in a continuous process while recovering the energy at the same time. The primary heat exchanger consists of a copper plate, which is cooled by water or thermal oil. The heat is extracted via conduction underneath the slag. The copper plate is mounted on a steel basin in which the thermal fluid (water or oil) captures the slag heat and cools the copper to prevent it from overheating and melting. The secondary heat exchanger comprises copper pipes with the same water or thermal oil circuit and extracts heat on the slag's upside via convection and radiation without direct contact to the slag. For the case of BFS, the correct temperature design is crucial for amorphous solidification. The transition temperature from module 1 to module 2 for blast furnace slags must be below the glass transition temperature. The tertiary heat exchanger-designed as batch process in the current process layout-extracts the heat by convection of air flowing through the bulk of solidified slag.

This process concept was tested with two demonstrators. The first demonstrator includes the primary and secondary heat exchanger as well as the slag tundish. The tests were performed in batches, but the demonstrators allow tests to be run in continuous operation. This is planned for pilot trials in an iron-making plant. The dimensions of the PHEdemonstrator are $820 \mathrm{~mm}$ in length and $255 \mathrm{~mm}$ in width. The copper plate has a thickness of $10 \mathrm{~mm}$ and is cooled by either water or thermal oil in inside channels below the copper plate, while in contact with liquid slag on the upper surface. The inner area being in contact with slag is $755 \mathrm{~mm} \times 155 \mathrm{~mm}$.

The entire PHE is set into vibration at a measured effective frequency of $47.6 \mathrm{~Hz} \pm 2.3 \mathrm{~Hz}$ and an amplitude of $0.45 \mathrm{~mm}$. The vibration unit of the demonstrator is an unbalance motor "NEA 50,300 electric external vibrator" from the supplier NetterVibration with a nominal power of $0.28 \mathrm{~kW}$ and a maximum centrifugal force of $2972 \mathrm{~N}$. The PHE is inclined by a variable angle between $0^{\circ}$ and $10^{\circ}$. The viscosity increase during solidification was calculated [15] for an exemplary blast furnace slag $\left(40 \% \mathrm{CaO}, 39 \% \mathrm{SiO}_{2}, 9.5 \%\right.$ $\left.\mathrm{MgO}, 11.5 \% \mathrm{Al}_{2} \mathrm{O}_{3}\right)$ and ranges from $8.9 \mathrm{~Pa} \mathrm{~s}\left(1450{ }^{\circ} \mathrm{C}\right)$ to $19.7 \mathrm{~Pa} \mathrm{~s}\left(850^{\circ} \mathrm{C}\right)$. This is relevant for the solidification on module 1 in the temperature range from pouring at $1450{ }^{\circ} \mathrm{C}$ to below the glass transition temperature of $850{ }^{\circ} \mathrm{C}$. However, the increase in viscosity did not appear as a problem throughout the tests.

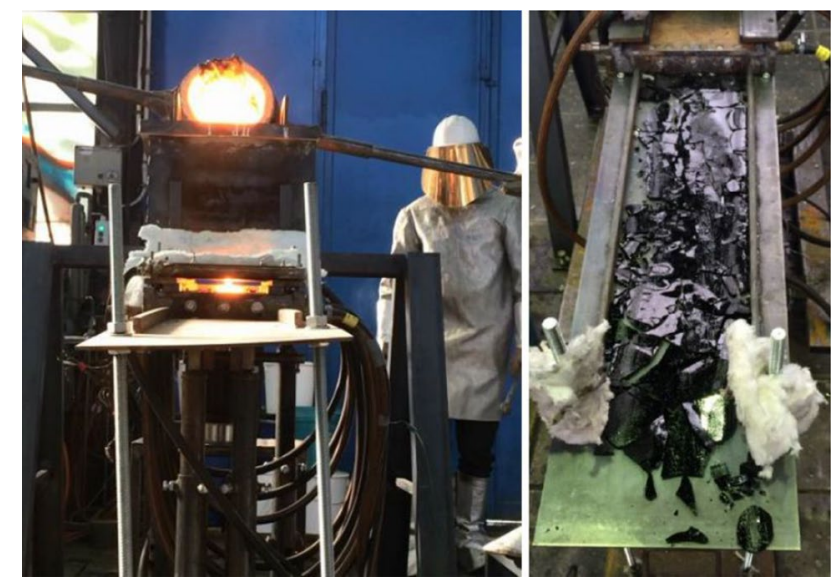

Fig. 3 Photograph of the first demonstrator during slag pouring in early stage (left) and vitreous solidified blast furnace slag after test and additional 30 min cooling at ambient air (right)

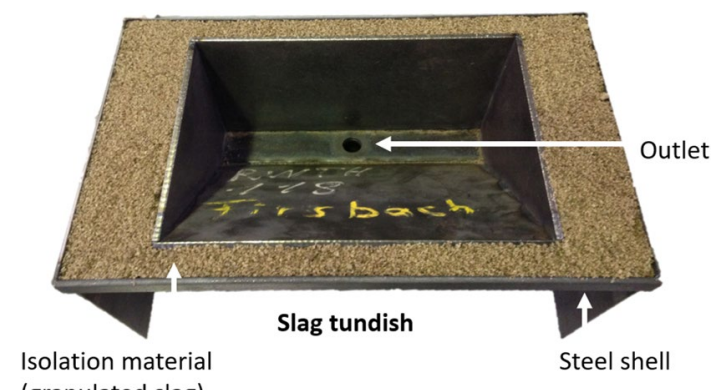

(granulated slag)

Fig. 4 Photograph of slag tundish before first heat with view from above

Mounted on the PHE is the secondary heat exchanger comprising bended copper pipes. The pipes have an inner diameter of $8 \mathrm{~mm}$ and a thickness of $1 \mathrm{~mm}$. Two concepts have been tested [14] with connection in parallel and in series. The concept with parallel connection was found to capture more thermal energy with slower flowing fluid than the connection in series. The parallel pipe connection setup was used for the tests leading to the present results. Both heat exchangers see the tapped slag and function simultaneously as shown in Fig. 3. They are fed by the slag tundish in Fig. 4.

Being aware that a slag tundish is a known and never successfully implemented concept to metallurgical research, this apparatus was necessary to mitigate the influence of the operators on the slag pouring and the resulting mass flow. The tundish consists of a steel shell and insulation material. For this study, un-ground-granulated BFS was chosen as insulation material. The outlet was regulated with a graphite sliding gate. The slag tundish was preheated with a natural gas burner to around 
$1000{ }^{\circ} \mathrm{C}$ before each test to reduce slag coating and cold spots.

The second demonstrator was equipped with the tertiary heat exchanger run in batch mode. This apparatus consists of a steel pipe of $400 \mathrm{~mm}$ height and a diameter of $205 \mathrm{~mm}$, as in Fig. 5. With the given bulk density of the hot vitreous blast furnace slag pieces (slag cullets), this demonstrator can be filled with up to $10 \mathrm{~kg}$ of slag at $850{ }^{\circ} \mathrm{C}$. Hot air is drawn from the bottom of the device which cools the slag cullets down to ambient temperature.

\section{Demonstrator Tests}

The following tests were designed to quantify the recuperation of thermal energy of the demonstrators as well as to gather necessary data for model simulations needed to design later upscaling models.

\section{Setup}

Demonstrator 1 -the 1 st module comprising PHE and SHE-was tested separately from demonstrator 2-the 2nd module comprising THE- to ensure identical material and thermal heat input into demonstrator 2. All tests on demonstrator 1 were performed with industrial GGBFS, which was molten in a graphite rod furnace via radiation heat. $6.5 \mathrm{~kg}$ of slag was manually tapped at $1550{ }^{\circ} \mathrm{C}$ into a ladle and then poured into the slag tundish. Tapping and buffering in the slag tundish resulted in an overall heat drop of the slag of around $100{ }^{\circ} \mathrm{C}$ despite the fact that the slag tundish was preheated with a natural gas burner to around $1000{ }^{\circ} \mathrm{C}$. The PHE cooling medium system (in this case water was used,

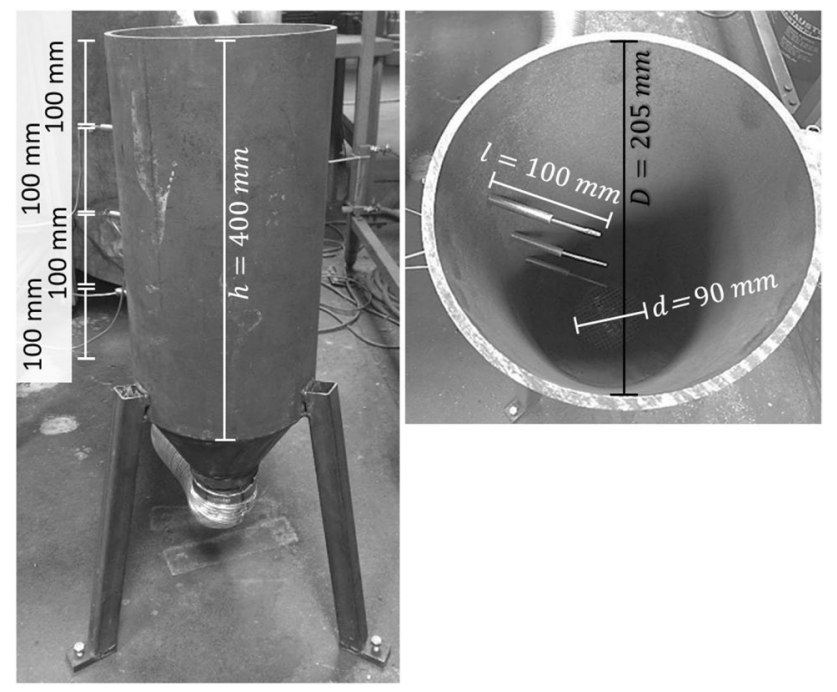

Fig. 5 Photograph of tertiary heat exchanger from the side (left) and above (right) in other tests [14] thermal oil) as well as the vibrating unit were turned on with a target frequency of $50 \mathrm{~Hz}$. The tundish sliding gate was partially opened to allow a slag flow $\dot{m}_{\mathrm{S}}$ of $20-26 \mathrm{l} / \mathrm{min}$. The temperature of the cooling medium was measured at the inlet and outlet. The recuperated energy $Q_{\mathrm{W}}$ was quantified by the temperature difference between water inlet and outlet $T_{\mathrm{w}, i}$, the density $\rho_{\mathrm{W}}(T)$, heat capacity $c_{\mathrm{W}, \mathrm{p}}(T)$, volume flow $\dot{V}_{\mathrm{W}}$, and test duration $\Delta t_{i}$, following Eq. (1). The provided input temperature of the slag was calculated according to Eq. (2) with the slag's heat capacity $c_{\mathrm{S}, \mathrm{p}}(T)$, temperature difference $\Delta T_{\mathrm{S}, i}$, as well as crystallization heat $\sum_{i}^{n} \Delta H_{\mathrm{c}} M$. The heat recuperation efficiency was calculated by Eq. (3):

$Q_{\mathrm{W}}=\sum_{i}^{n} \rho_{\mathrm{W}}(T) c_{\mathrm{W}, \mathrm{p}}(T) \Delta T_{\mathrm{w}, i} \Delta t_{i} \dot{V}_{\mathrm{W}}$,

$Q_{\mathrm{S}}=\sum_{i}^{n} c_{\mathrm{S}, \mathrm{p}}(T) \Delta T_{\mathrm{S}, i} \Delta t_{i} \dot{m}_{S}+\sum_{i}^{n} \Delta H_{\mathrm{c}} M$,

$\eta=\frac{Q_{\mathrm{W}}}{Q_{\mathrm{S}}} 100 \%$.

A similar approach was taken for demonstrator $2.10 \mathrm{~kg}$ of slag cullets produced on demonstrator 1 were heated to $850{ }^{\circ} \mathrm{C}$ in a muffle furnace. They were introduced manually into demonstrator 2 , and an air pump was turned on to initiate the cooling tests until the slag reached $50{ }^{\circ} \mathrm{C}$. The cooling medium was ambient air, which was drawn from the environment and heated up while passing through the hot slag cullet bulk. The air temperature was measured before and after contact with the hot slag cullets, and the recovered thermal energy was calculated similar to $Q_{\mathrm{W}}$ using Eq. (1). Varying the air velocity from 0.6 to $8.8 \mathrm{~m} / \mathrm{s}$ allowed to quantify different recuperation efficiencies.

\section{Demonstrator Results}

The recuperation efficiency of the first module with water around $24 \%$ of the total blast furnace slag's energy and is at a temperature step of $-600 \mathrm{~K}$, while cooling from 1450 to $850{ }^{\circ} \mathrm{C}$. In the second module, the temperature step is $-800 \mathrm{~K}$ and the recuperation efficiency was quantified with $18 \%$ of the total blast furnace slag's energy. The overall recuperation efficiency totals to $42 \%$ for the same slag (Fig. 6). From an initial energy of $1.7 \mathrm{GJ} / \mathrm{t}$ of BFS slag, it was possible to recover $0.7 \mathrm{GJ} / \mathrm{t}$ of BFS slag leaving an amorphous endproduct. The energy loss via the vibrating unit was between 0.7 and $1.2 \mathrm{kWh} / \mathrm{t}$ slag for $60-100 \mathrm{~s}$ vibration for $6.5 \mathrm{~kg}$ of solidifying slag. This corresponds to $2.6-4.3 \mathrm{MJ}_{\text {electric }} / \mathrm{t}$ slag and to $0.4-0.6 \%$ of the recovered slag 
Fig. 6 Sankey diagram on the recuperation and heat losses of the process concept measured on blast furnace slag
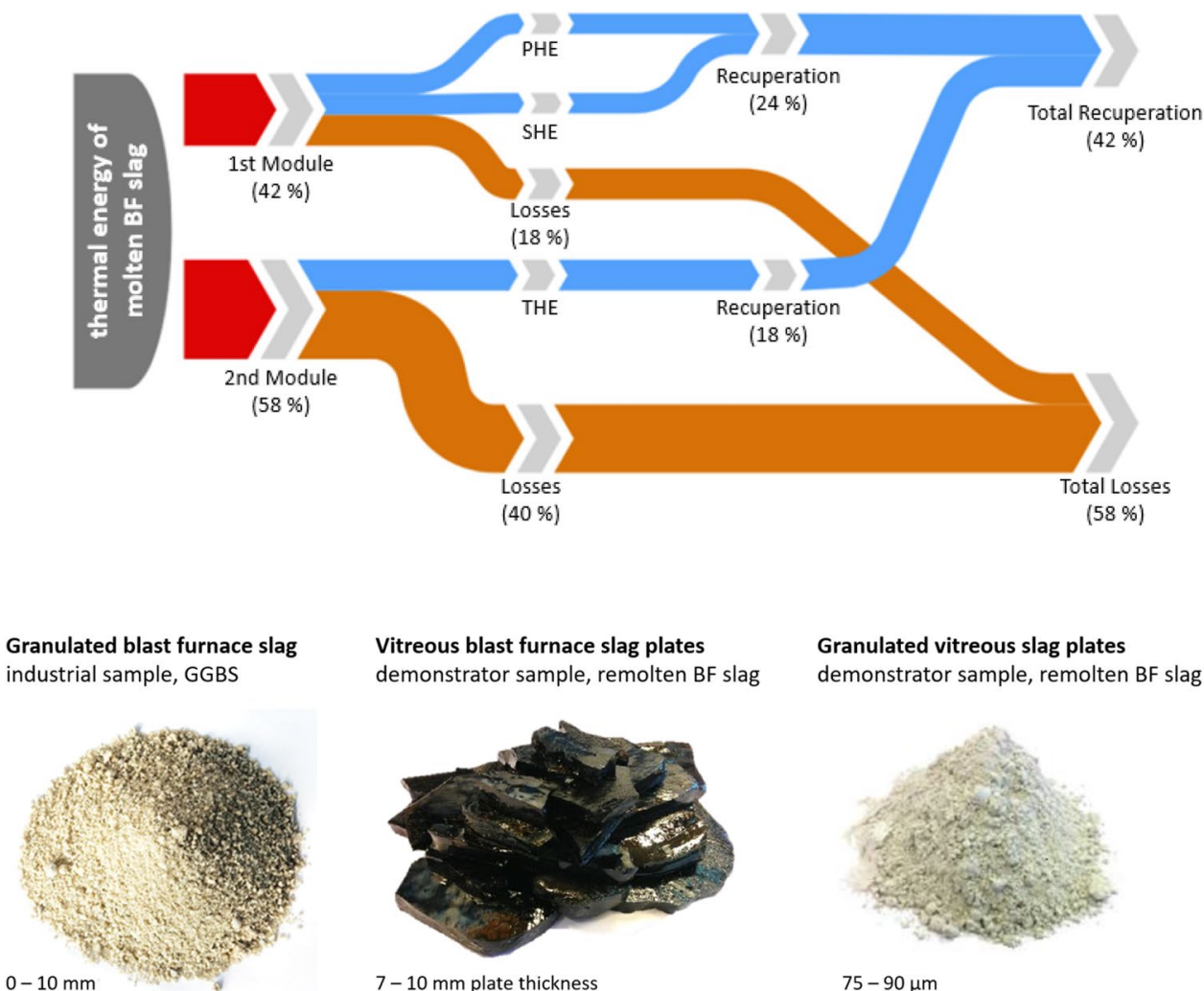

Vitreous blast furnace slag plates

Granulated vitreous slag plates demonstrator sample, remolten BF slag

demonstrator sample, remolten BF slag

compared to vitreous blast furnace slag plates produced on demonstrator (middle) and milled afterwards (right)
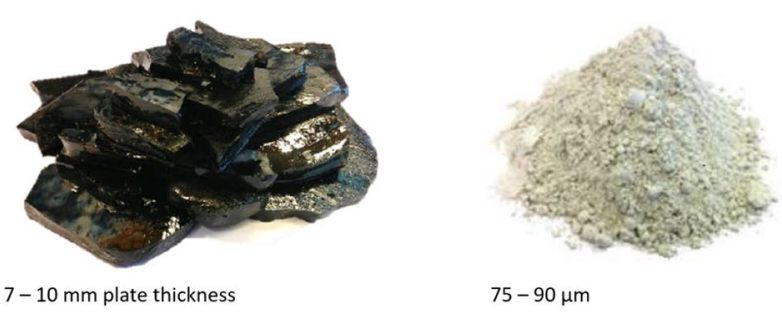

$75-90 \mu \mathrm{m}$

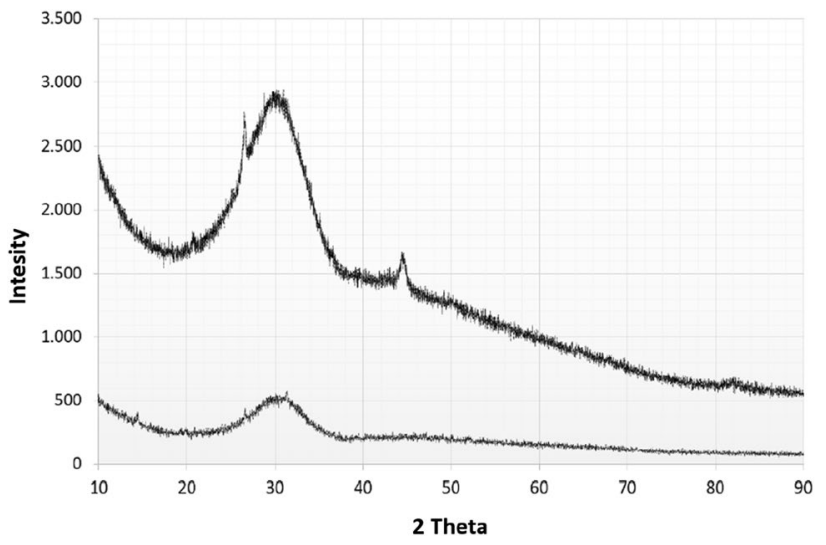

Fig. 8 X-ray diffraction pattern of two exemplary slag plates being $>0.950 \mathrm{~g} / \mathrm{g}$ vitreous

\section{Stress Test with Liquid Hot Metal}

Tapped blast furnace slag can contain droplets of liquid hot metal, which is hazardous for copper and could result in serious wear of the PHE. To address this operational challenge, two tests were carried out with hot metal having the chemical composition as shown in Table 2. The hot metal was heated to $>1550{ }^{\circ} \mathrm{C}$ and approx. $870 \mathrm{~g}$ was poured with a cast spoon directly onto PHE with an average mass 
Table 2 Heat transfer calculations differentiating case 1 (common test results) and case 2 (exceptional results)

\begin{tabular}{lllllll}
\hline Element & $\mathrm{C}$ & $\mathrm{Si}$ & $\mathrm{Mn}$ & $\mathrm{P}$ & $\mathrm{S}$ & $\mathrm{Fe}$ \\
\hline $\mathrm{Wt} \%$ & 3.67 & 1.36 & 0.099 & 0.035 & 0.010 & $\mathrm{Rest}$ \\
\hline
\end{tabular}

Fig. 9 Top casting of $870 \mathrm{~g}$ of hot metal on the demonstrator; bottom solidified hot metal after test

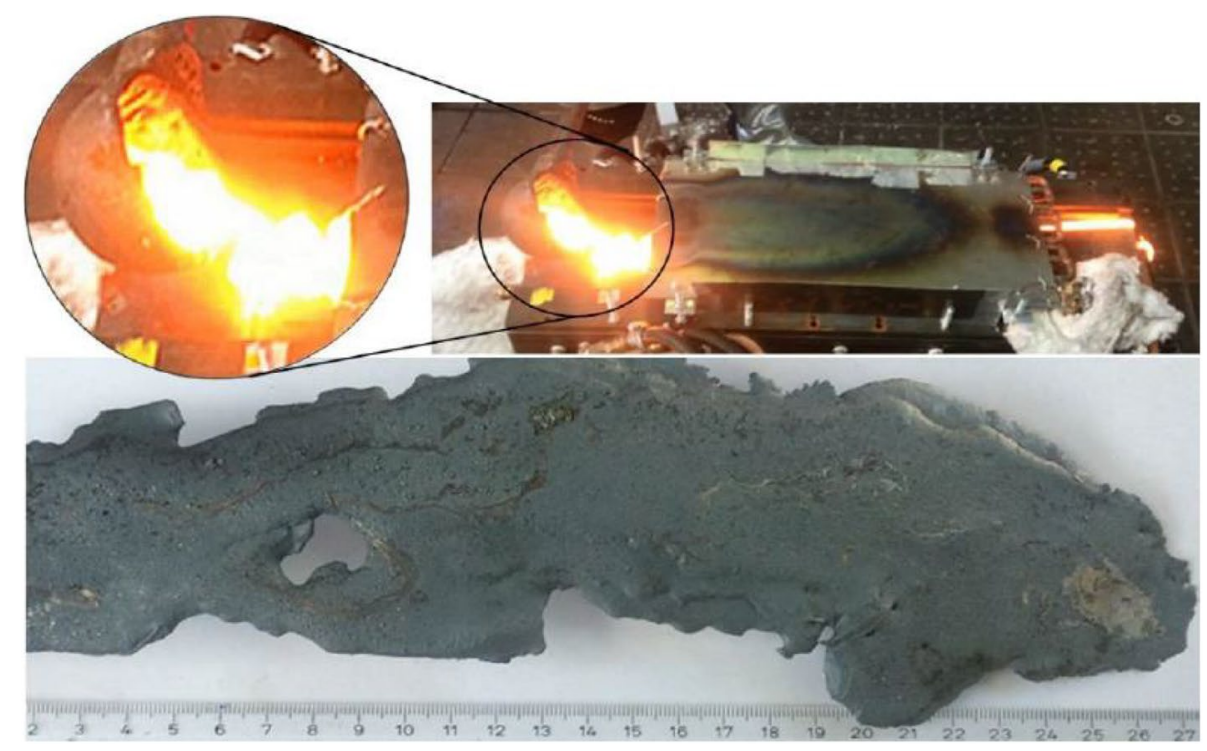

flow of $1.3 \mathrm{~kg} / \mathrm{s}$. The PHE was cooled with the typical $18 \mathrm{l} /$ min water, at a temperature of around $15{ }^{\circ} \mathrm{C}$.

The exemplary stress test in Fig. 9 with hot metal was considered harmless with regard to the wear of the copper plate. The tests did not show that direct contact with hot metal leads to corrosive and erosive wear characteristics in the short term. In terms of industrial operations, however, it should not be neglected that hot metal present as droplets in the slag could lead to copper wear in the long term.

\section{Simulation of Inclination Influence on Heat Transfer}

The heat recovery can be influenced by the inclination angle $\theta$ of the PHE in regard of slag mass flow. The hypothesis was that changing the contact duration either by changing the inclination could impact the recuperation. In the following simulation, the inclination angle was increased stepwise while maintaining the same vibration frequency. The hypothesis stated that this would lead to larger slag jumping gaps and therefore smaller ratios between conduction slag/ copper and convection slag/air, as well as larger slag mass flow on the PHE resulting in reduced contact times slag/ copper. Next to possible changes in the vibration frequency, the change of the inclination angle is a simple measure to control the mass flow and slag solidification for pilot trials of an upscaled unit. The simulated system is drawn in Fig. 10.

Simulations were conducted with the software MATLAB ${ }^{\circledR}$. For the simulations, a heat transfer coefficient was

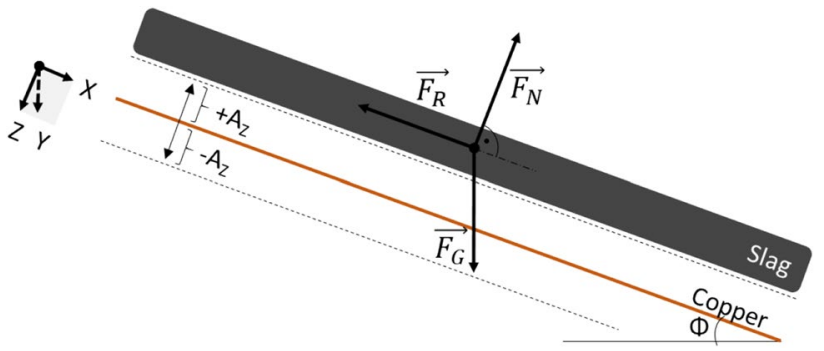

Fig. 10 Coordinate system of the slag chute including inclination $\theta$, amplitude $A_{\mathrm{Z}}$ in $z$-direction, force of friction $F_{\mathrm{R}}$, gravitational force $F_{\mathrm{G}}$, and normal force $F_{\mathrm{N}}$

assumed at $1300 \mathrm{~W} / \mathrm{m}^{2} \mathrm{~K}$ for full slag/copper contact and for convection of a thin gap of $1 \mathrm{~mm}$ at $300 \mathrm{~W} / \mathrm{m}^{2} \mathrm{~K}$ in comparison to heat transfer phenomena of a steel tundish [17]. The PHE vibrating amplitude $A_{Z}$ in vertical direction of the PHE surface was assumed to be $0.45 \mathrm{~mm}$, the kinetic friction of the cooper $\mu_{\text {kinetic }}$ to be 0.16 [17] and air friction was neglected. With these assumptions, it was possible to simulate that the average velocity solidifying slag would have on the PHE with increasing inclination. Figure 11 shows that at small angles, the slag's velocity is $0.015 \mathrm{~m} / \mathrm{s}$. With increasing inclination, the velocity will reach $12 \mathrm{~m} / \mathrm{s}$ until reaching a state of free fall at $90^{\circ}$. The apparent slag velocity during demonstrator tests was quantified to be between 0.013 and $0.017 \mathrm{~m} / \mathrm{s}$ for solidified BFS. 


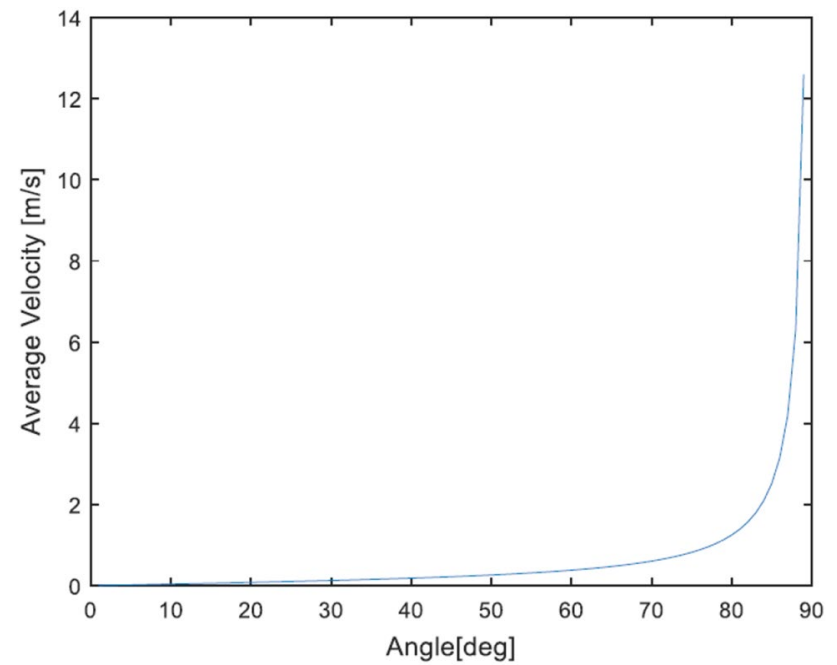

Fig. 11 Change of average velocity in $x$-direction with angle at $z$-direction vibration

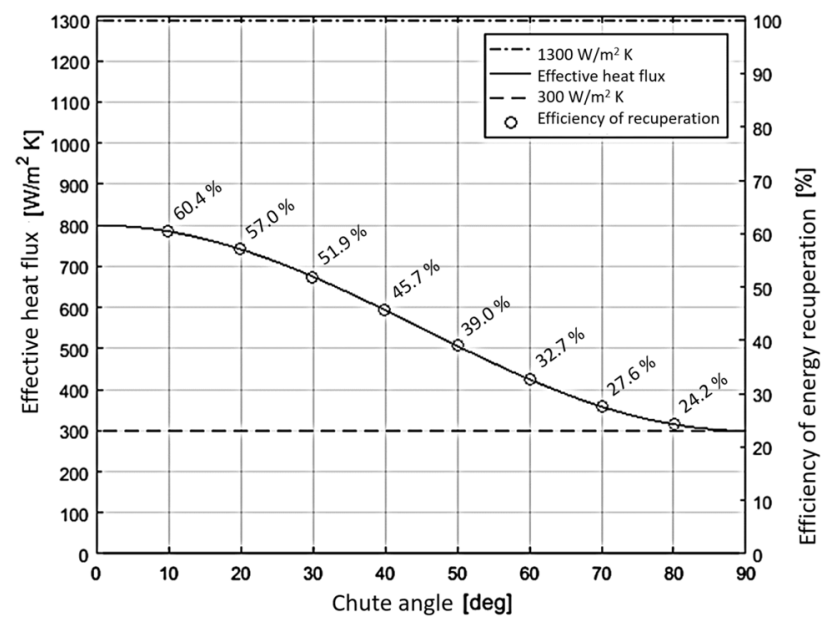

Fig. 12 Influence of chute angle on heat transfer

At $6^{\circ}$ inclination the heat transfer coefficient was simulated to be $794.5 \mathrm{~W} / \mathrm{m}^{2} \mathrm{~K}$, as presented in Fig. 12. Although the assumed amplitude, also quantified previously, gives an indication on the movement of the PHE, it is not identical to the shortest distance of the slag and the PHE. Smaller inclination angles lead to higher heat transfer coefficient while larger inclinations decreased the heat transfer coefficient to the assumed limit of $300 \mathrm{~W} / \mathrm{m}^{2} \mathrm{~K}$. The heat transfer coefficient was measured to be 577 to $766 \mathrm{~W} / \mathrm{m}^{2} \mathrm{~K}$, as shown in Table 3. It can be found that the simulated results are up to $27 \%$ higher than the measured results, which might be due to the self-insulating nature of slag as the simulated results indicate theoretical maximal heat transfer coefficient inside the solidified slag, while the experimental results actual heat transfer coefficient inside the slag might be lower.
Table 3 Heat transfer calculations differentiating case 1 (common test results) and case 2 (exceptional results)

\begin{tabular}{llll}
\hline Parameter & Case 1 & Case 2 & Unit \\
\hline Tapping temperature & 1450 & 1450 & ${ }^{\circ} \mathrm{C}$ \\
Final temperature & 850 & 850 & ${ }^{\circ} \mathrm{C}$ \\
Temperature difference & 600 & 600 & $\mathrm{~K}$ \\
Contact area, PHE & 0.116 & 0.116 & $\mathrm{~m}^{2}$ \\
Inclination, PHE & 6 & 6 & ${ }^{\circ} \mathrm{C}$ \\
Contact time, PHE & 60 & 45 & $\mathrm{~s}$ \\
Slag velocity & 0.013 & 0.017 & $\mathrm{~m} / \mathrm{s}$ \\
Slag mass flow & 0.20 & 0.27 & $\mathrm{t} / \mathrm{h}$ \\
Recovered heat & 0.77 & 0.77 & $\mathrm{GJ} / \mathrm{t}$ \\
Heat transfer coefficient & 574 & 766 & $\mathrm{~W} / \mathrm{m}^{2} \mathrm{~K}$ \\
\hline
\end{tabular}

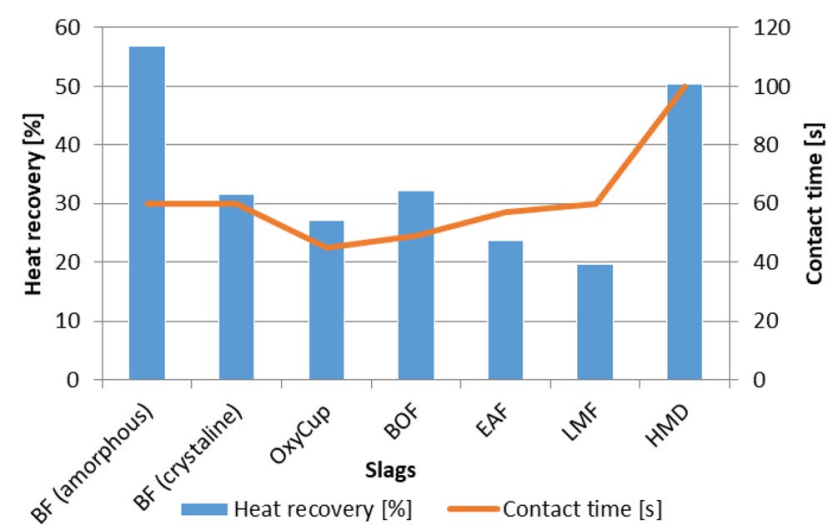

Fig. 13 Heat recuperation of different ferrous slags on demonstrator 1 shows differing energetic recovery yields. The abbreviations stand for blast furnace, basic oxygen furnace, electric arc furnace, ladle metallurgy furnace, and hot metal desulfurization

Next to the concept of investigating the possibility to recover BFS thermal energy, the same challenge is present for the heat recovery of other metallurgical slags, ferrous or non-ferrous. This challenge could also be addressed with the proposed solution. Ferrous slags from different processes were molten and treated according to the previously described process to obtain exemplary results. Figure 13 shows the results obtained with the demonstrator 1 . Viscosities and wettability of the copper with the mentioned slags lead to different velocities and, therefore, to different contact times. These contact times partially explain the differences in recovered thermal heat, but it is assumed that chemistry and (changing) mineralogy are also to be considered. It is to be noted that one test of a BFS provided the data for the first two bars in Fig. 13. These bars help to indicate that when considering a slag which should solidify vitreous, the available crystallization energy could be excluded from the recoverable energy which then would lead to an increase of the heat recuperation by calculation only. Hence, 
for the evaluation of the present process concept only, the full thermal energy potentials of slags are considered. It is also to be noted that for ground-granulated blast furnace slag (GGBFS), the crystallization energy has to stay entrapped in the vitreous material in order to be valuable for the cement process.

\section{Energy Utilization}

Having developed the described process for slag heat recovery with the conditions of (1) quantifying yields of slag energy recovery and (2) amorphous solidification of BFS, it is necessary to evaluate ways of its energetic utilization. Conversion of the recovered thermal energy to electrical energy is a possibility which is of technological but not economical interest for integrated plants. Integrated plants are usually self-sufficient in electrical energy production via electrification of blast furnace off-gas as well as coke oven gas. Hence, three scenarios were theoretically investigated to interlink the slag heat recovery with other thermal process of integrated steel plants. These are concept ideas for the aforementioned quaternary heat exchanger. The following calculations are based on energy demands of three selected processes:

1. Hot-blast generation by Cowper

2. Bio-coal production via torrefaction

3. Reduction gas (syngas) generation by high-temperature winkler process

\section{Heating of BF Hot Stoves}

The first scenario is the use of obtained energy for the heating of BF hot stoves. In reference to the exemplary blast furnace of Table 1, it was indicated that such furnace needs a hot air rate of $200,000 \mathrm{Nm}^{3} / \mathrm{h}$. The thermal energy to heat the cold air from $11{ }^{\circ} \mathrm{C}$ up to become hot blast of $1100{ }^{\circ} \mathrm{C}$ is $2000 \mathrm{TJ} / \mathrm{a}$. Recovering $100 \%$ of the BFS energy would

Table 4 Hot-blast parameters for of the BF in Table 1 and required slag thermal energy

\begin{tabular}{lll}
\hline Parameter & Value & Unit \\
\hline Hot blast & 200,000 & $\mathrm{Nm} / \mathrm{h}$ \\
Density & 1.12 & $\mathrm{~kg} / \mathrm{m}^{3}$ \\
Temperature difference & 1089 & $\mathrm{~K}$ \\
Specific heat capacity of air & 1.005 & $\mathrm{~kJ} / \mathrm{kg} \mathrm{K}$ \\
Energy needed & 2148 & $\mathrm{TJ} / \mathrm{a}$ \\
Slag thermal energy & 1098 & $\mathrm{TJ} / \mathrm{a}$ \\
Slag heat recovery & 100 & $\%$ \\
Covered energy demand & 51.1 & $\%$ \\
\hline
\end{tabular}

provide around $50 \%$ of the energetic demand and could lead to reduction in consumption of fuel gas or higher hot blast temperature (Table 4).

\section{Bio-coal Production via Torrefaction}

Scenario two is including the installation of a torrefaction unit to produce bio-coal for said blast furnace of Table 1 to replace a part of the necessary coke. The biomass has insufficient energy density, which requires densification and moisture, which requires drying. The first step in a torrefaction unit is drying and preheating, which is usually done with torrefaction torgas and wet biomass, Fig. 14. To provide the necessary thermal energy demand for the drying step, instead of igniting torgas and biomass, recovered slag heat could be utilized. The energy demand to replace $5 \%$ of the necessary coke with biomass is $133 \mathrm{TJ} / \mathrm{a}$ and would be covered 8 times by BFS heat at $100 \%$ recovery (see Table 5 ). At $42 \%$ heat recovery quantified via the demonstrator setups, the energy demand would be covered approx. 3.5 times.

\section{Reducing Gas Generation by High Temperature Winkler Process}

Scenario three is the gasification of biomass to produce reduction gas for said blast furnace via a high temperature

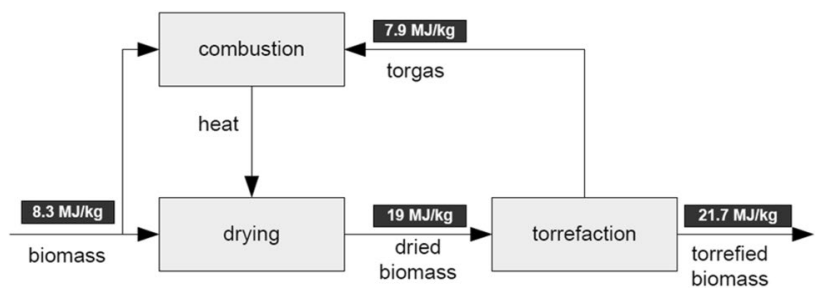

Fig. 14 Exemplary biomass drying and torrefaction process without the usage of recovered slag heat [21]

Table 5 Required slag thermal energy to replace $5 \%$ of coke by biocoal in the BF of Table 1

\begin{tabular}{lll}
\hline Parameter & Value & Unit \\
\hline Coke rate & 350 & $\mathrm{~kg} / \mathrm{tHM}$ \\
Annual coke amount & 753,725 & $\mathrm{t} / \mathrm{a}$ \\
Torrefied biomass required & 37,686 & $\mathrm{t} / \mathrm{a}$ \\
Raw biomass required (according to [21]) & 95,743 & $\mathrm{t} / \mathrm{a}$ \\
Raw biomass moisture & 50 & $\%$ \\
Specific energy for drying 50\% moisture [21] & 1.39 & $\mathrm{MJ} / \mathrm{kg}$ \\
Energy for drying, total & 133 & $\mathrm{TJ} / \mathrm{a}$ \\
Slag thermal energy & 1098 & $\mathrm{TJ} / \mathrm{a}$ \\
Slag heat recovery & 100 & $\%$ \\
Covered air energy demand & 825 & $\%$ \\
\hline
\end{tabular}




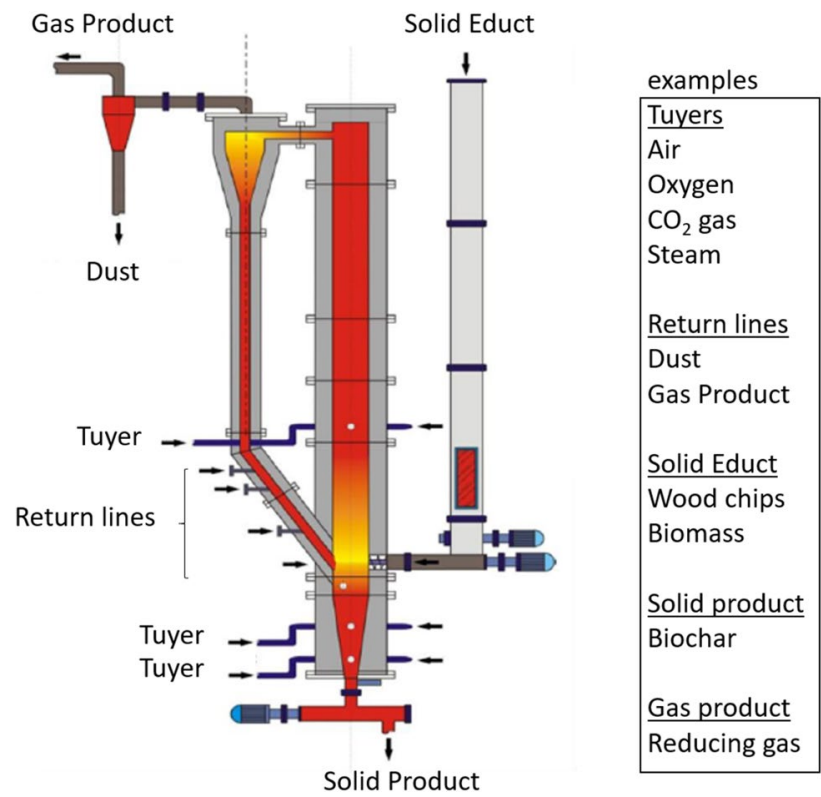

Fig. 15 Schematic of a high-temperature winkler process

Table 6 Production reducing hot blast for described blast furnace of Table 1 calculated based on experimental data [18]

\begin{tabular}{lll}
\hline Parameter & Value & Unit \\
\hline Reducing hot gas & 200,000 & $\mathrm{Nm}^{3} / \mathrm{h}$ \\
Raw wood needed & 100 & $\mathrm{t} / \mathrm{h}$ \\
Hot air needed & 105,000 & $\mathrm{Nm}^{3} / \mathrm{h}$ \\
Hot air temperature needed & 310 & ${ }^{\circ} \mathrm{C}$ \\
Energy needed & 280 & $\mathrm{TJ} / \mathrm{a}$ \\
Slag thermal energy & 1098 & $\mathrm{TJ} / \mathrm{a}$ \\
Slag heat recovery & 100 & $\%$ \\
Covered air energy demand & 370 & $\%$ \\
\hline
\end{tabular}

winkler process, as shown in Fig. 15. For the following calculations, experimental data from Ising et al. [18] of gasification of raw wood biomass have been used. The obtained reducing hot gas would have $930{ }^{\circ} \mathrm{C}$ and a composition of $18 \mathrm{vol} \% \mathrm{CO}, 13 \mathrm{vol} \% \mathrm{CO}_{2}, 4 \mathrm{vol} \% \mathrm{CH}_{4}, 7 \mathrm{vol} \%$ $\mathrm{H}_{2}, 10$ vol\% $\mathrm{H}_{2} \mathrm{O}$ and 48 vol $\% \mathrm{~N}_{2}$ assuming Ising et al. [18] pilot trial results. With the $\mathrm{CO}$ and $\mathrm{H}_{2}$ contained in the gasification gas, such hot blast would be reducing and could partially substitute coke or pulverized coal injection (PCI). The air needed for this gasification requires preheating to $310{ }^{\circ} \mathrm{C}$. Recovered slag heat at $100 \%$ yield would provide close to four times the energetic demand for the needed hot air to produce $200,000 \mathrm{Nm}^{3} / \mathrm{h}$ reducing gas, Table 6.

\section{Conclusions}

Slags are recycled in large scale and already contribute largely to $\mathrm{CO}_{2}$-footprint reduction, circular economy, and metallurgical sustainability. While some of their material potential is valorized, their thermal potential still lies unused. A process concept for slag heat recovery was investigated with a lab-scale demonstrator. The key findings of this study are

1. The presented approach offers a process to recuperate thermal energy from ferrous slags in the temperature range from tapping to ambient temperature.

2. The thermal recuperation efficiencies with the demonstrator were quantified for blast furnace slag to be $42 \%$ while producing $>95 \mathrm{Vol} \%$ vitreous blast furnace slag cullets.

3. The milling energy for such slag cullets was quantified to be $9 \mathrm{kWh} / \mathrm{t}$.

4. Utilization of thermal energy might be best accomplished by interlinking processes, e.g.,

a. Heating of BF hot stoves

b. Bio-coal production via torrefaction

c. Reducing gas (syngas) generation by high-temperature winkler process

5. Hot-blast generation with Torrefaction or high-temperature winkler process is not common technologies for integrated steel plants. The ecological, political, and social pressure to decarbonize steelmaking and foster circular economy give these technologies a second life. New approaches lead such a trend, like the BASE method [19]. The BASE method couples blast furnace with a pyrolysis reactor and shows that by interlinking of processes, like the presented slag heat recovery for the utilization of biomass in iron and steelmaking can become reality.

\section{Outlook}

This entire process concept was tested on two demonstrators including slag tundish, primary, secondary, and tertiary heat exchangers. An upscaled pilot facility should be the next step of the development. Cementitious properties of vitreous blast furnace slag produced on the present process should be quantified.

Acknowledgements We thank Z\&J Technologies GmbH, and namely Sebastian Buzga, for the funding and Salzgitter Flachstahl GmbH, and namely Dr.-Ing. Jürgen Pethke, for the support and fruitful discussions. 
Further we would like to thank Dr. Alexander Babich for the support regarding the utilization of recovered heat for torrefaction and Lhoist for allowing his employer to further contribute to the present research. We also thank Prof. "HeiWi" Gudenau for initiating this research in another millennia when steelmaking was different than today.

Funding Open Access funding enabled and organized by Projekt DEAL.

\section{Declarations}

Conflict of interest On behalf of all authors, the corresponding author states that there is no conflict of interest.

Open Access This article is licensed under a Creative Commons Attribution 4.0 International License, which permits use, sharing, adaptation, distribution and reproduction in any medium or format, as long as you give appropriate credit to the original author(s) and the source, provide a link to the Creative Commons licence, and indicate if changes were made. The images or other third party material in this article are included in the article's Creative Commons licence, unless indicated otherwise in a credit line to the material. If material is not included in the article's Creative Commons licence and your intended use is not permitted by statutory regulation or exceeds the permitted use, you will need to obtain permission directly from the copyright holder. To view a copy of this licence, visit http://creativecommons.org/licenses/by/4.0/.

\section{References}

1. Senk D (2015) Firsbach, Felix. 3rd International VDEh-Seminar, Cologne

2. MSG Mineralstoffgesellschaft Saar mbH, Konverterkalk feuchtkörnig, Material Datasheet, https://www.dillinger.de/d/downloads/ download/15546. Accessed 19 Mar 2021

3. Pikna L, Hezelova M, Morillon A, Algermissen D, Milkovic O, Findorak R, Cesnek M, Briancin J (2020) Recovery of chromium from slags leachates by electrocoagulation and solid product characterization. Metals 10(12):1593

4. Kremer D, Wotruba $\mathrm{H}$ (2020) Separation of products from mineral sequestration of $\mathrm{CO}_{2}$ with primary and secondary raw materials. Minerals 10(12): 1098

5. Gudenau H-W, Lidner K-H, Maas H, Peters K-H (1986) Schlackenabwärmenutzung. Stahl Eisen 106(23):1281-1286

6. Shigaki N, Tobo H, Ozawa S, Ta Y, Kazuma H (2015) Heat recovery process from packed bed of hot slag. ISIJ Int 10:2258-2265

7. Yoshida H, Nara Y, Nakatani G, Anzai T, Sato H (1984) Technology of slag heat recovery at NKK. South East Asia Iron Steel Institute
8. Faucher S, So LC, Mostaghel S, Lee SK, Oh SY (2016) Recent developments in commercial scale dry slag granulation and energy recovery. AISTech conference, Pittsburgh

9. Barati M, Jahanshahi S (2015) Dry granulation and heat recovery from metallurgical slags. In: Slag valorisation symposium, Mechelen, Belgium

10. Xie D, Jahanshahi S (2008) Waste heat recovery from molten slags. In: International congress on the science and technology of steelmaking, Gifu, Japan

11. Fenzl T (2020) A significant change in slag treatment-an update on industrial dry slag granulation. In: Global slag conference, 10 November 2020

12. Algermissen D, Böhlke P, Hugenschütt G, Raßfeld U, Zehn T (2016) Definierte Erstarrung und Wärmerückgewinnung von Elektroofenschlacke (DEWEOS). FEhS Rep 2:12-19

13. Hüttenmeister D (2015) Entwicklung einer Anlage zur amorphen Erstarrung flüssiger Hochofenschlacke mit gleichzeitiger Wärmerückgewinnung, Dr.-Ing. Thesis, RWTH Aachen University, Shaker Verlag Aachen

14. Firsbach F (2018) Konstruktion und prozesstechnische Optimierung einer Anlage zur amorphen und rekuperativen Erstarrung von Schlackensystemen integrierter Hüttenwerke, Dr.-Ing. Thesis, RWTH Aachen University, Shaker Verlag Aachen

15. Zhang G-H, Chou K-C, Mills K (2014) A structurally based viscosity model for oxide melts. Metall Mater Trans B 45(2):698-706

16. Ehrenberg A (2006) Hüttensand - Ein leistungsfähiger Baustoff mit Tradition und Zukunft. Beton-Informationen, 5:67-95

17. Falkus J, Miłkowska-Piszczek K, Rywotycki M, Wielgosz E (2012) The influence of the selected parameters of the mathematical model of steel continuous casting on the distribution of the solidifying strand temperature. J Achievements Mater Manuf Eng 55:668-672

18. Ising M, Hölder D, Backhaus C, Althaus W (1998) Vergasung von Biomasse in der zirkulierenden Wirbelschicht. DGMK Tagungsbericht 9802:177-184

19. Babich A, Senk D, Solar J, de Marco I (2012) Efficiency of biomass use for blast furnace injection. ISIJ Int 59(12):2212-2219

20. Papapetroua M, Kosmadakis G, Cipollinaa A, LaCommareaMicalea UG (2018) Industrial waste heat: estimation of the technically available resource in the EU per industrial sector, temperature level and country. Appl Therm Eng 138:207-216

21. Koppejan J, Sokhansanj S, Melin S, Madrali S (2019) Status overview of torrefaction technologies. IEA Bioenergy Task 32 report, p 5

Publisher's Note Springer Nature remains neutral with regard to jurisdictional claims in published maps and institutional affiliations. 